\title{
Pengaruh Pandemi COVID-19 Terhadap Pelaksanaan Tradisi Ngabuburit pada Mahasiswa di Kota Bandung
}

\author{
Isaac Bernadus*1, Nadien Proton ${ }^{2}$, Syifa Hanifah ${ }^{3}$ \\ ${ }^{1}$ Program Studi Teknik Fisika Fakultas Teknologi Industri Institut Teknologi Bandung, \\ ${ }^{2}$ Program Studi Desain Komunikasi Visual Institut Teknologi Bandung, ${ }^{3}$ Program Studi Desain \\ Produk Institut Teknologi Bandung

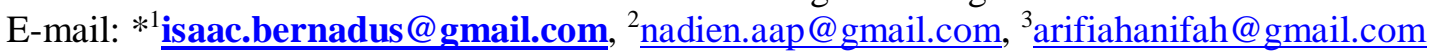

\begin{abstract}
Abstrak
Tradisi Ngabuburit pada masyarakat Indonesia merupakan budaya yang sudah melekat secara turun-temurun. Namun, pelaksanaan tradisi ngabuburit baru-baru ini terhambat disebabkan oleh pandemi COVID-19. Untuk mencegah penyebaran penyakit COVID-1, pemerintah mengeluarkan beberapa peraturan. Peraturan-peraturan tersebut mempersulit masyarakat untuk melaksanakan budaya Ngabuburit. Penelitian ini dilakukan untuk mengetahui seberapa besar pengaruh pandemi COVID-19 terhadap budaya ngabuburit, mengetahui minat mahasiswa Bandung dalam pelaksanaan tradisi ngabuburit, dan mencari tahu metode yang paling tepat dalam pelaksanaan tradisi Ngabuburit saat pandemi menurut mahasiswa. Metode yang digunakan pada penelitian ini adalah studi literatur, serta pengambilan data primer melalui penyebaran kuesioner. Hasil penelitian menunjukkan bahwa pandemi COVID-19 telah menurunkan intensitas pelaksanaan tradisi Ngabuburit di Bandung. Terhambatnya pelaksanaan tradisi Ngabuburit memiliki korelasi dengan menurunnya rata-rata tingkat kebahagiaan mahasiswa di Kota Bandung. Walaupun pelaksanaan tradisi Ngabuburit terhambat, tradisi Ngabuburit tetap dapat dilakukan dengan menggunakan metode daring, yaitu metode yang mengandalkan kemajuan teknologi sehingga tidak perlu bertatap muka. Penelitian ini kiranya dapat bermanfaat bagi pihak yang ingin melaksanakan tradisi Ngabuburit di tengah pandemi COVID-19.
\end{abstract}

Kata Kunci-Ngabuburit, COVID-19, Pandemi, Penyebaran

\begin{abstract}
Ngabuburit in Indonesian society is a tradition that has been inherited from past generations. The practice of Ngabuburit however has been hampered due to the COVID-19 pandemic. To prevent the spread of COVID-19 virus, the government issued several regulations. These regulations make it more difficult for the community to practice Ngabuburit. This study was conducted to find out the effects of the COVID-19 pandemic on Ngabuburit, the interest of university students in Bandung in practicing Ngabuburit, and to find out the best method to practise Ngabuburit tradition amidst the COVID-19 pandemic according to university students. Methods used in this study are literature study and primary data collection through questionnaires. The research result indicates that COVID-19 pandemic has reduced the intensity of Ngabuburit in Bandung. The obstruction of Ngabuburit practices correlates with the decline in the average level of happiness of students in Bandung. Even though the practice of Ngabuburit tradition is hampered, said tradition still can be carried out through online methods, namely methods that rely on internet technology so that there is no need to meet face to face. Hopefully this research will be useful for those who wish to practise Ngabuburit tradition amidst the COVID-19 pandemic.
\end{abstract}

Keywords - Ngabuburit, COVID-19, Pandemic, Transmission 


\section{PENDAHULUAN}

\subsection{Latar Belakang}

Penduduk Indonesia memiliki beragam hal unik yang tersebar di Nusantara. Bukan hanya memiliki keberagaman suku bangsa, melainkan juga budaya dan tradisi. Salah satu tradisi yang masih dilaksanakan adalah tradisi Ngabuburit. Tradisi Ngabuburit merupakan salah satu tradisi yang dilaksanakan selama bulan puasa sembari menunggu azan magrib, terutama di wilayah Jawa Barat. Lembaga Bahasa dan Sastra Sunda menyatakan bahwa istilah Ngabuburit diambil dari kalimat "Ngalantung ngadagoan burit". Definisi ketiga kata tersebut menurut Kamus Umum Basa Sunda [1] adalah "Berjalan-jalan (dengan senang)", "menunggu", dan "senja". Dengan demikian, Ngabuburit memiliki arti berjalan-jalan menunggu senja. Awalnya, masyarakat melaksanakan tradisi ini dengan mengikuti kegiatan keagamaan, begitu pula yang dilakukan masyarakat Sunda saat itu. Menunggu waktu berbuka puasa di dalam masjid dengan mengaji dan mendengarkan dakwah, sudah tidak asing lagi karena berkaitan dengan hakikat Ngabuburit yang telah dijalani menurut masyarakat Sunda pada masa lalu . Namun, seiring dengan perkembangan zaman, Ngabuburit tidak hanya dikaitkan dengan kegiatan religius, melainkan dengan kegiatan non religius lainnya. Pada masa lalu pula, penduduk Kota Bandung melakukan tradisi Ngabuburit dengan beramai-ramai ke taman, lapangan olahraga, berenang, dan berperahu di Situ Aksan atau Situ Bunjali. Warga kota Bandung tempo dulu biasanya mengunjungi tempat bermain air, seperti Empang Cipaganti milik Haji Sobandi, Pemandian Cihampelas, atau Situ Aksan yang menyediakan fasilitas penggunaan perahu. Selain itu, taman yang menjadi daya tarik untuk dinikmati pemandangannya oleh warga saat Ngabuburit tersebut adalah Jubileum Park (Taman Sari), Insulinde Park (Taman Lalu Lintas), Molukken Park (Taman Maluku), serta taman lainnya. Pada zaman modern, kegiatan Ngabuburit seringkali meliputi kegiatan, seperti berbelanja, wisata kuliner untuk disimpan setelah azan magrib, bakti sosial, dan mengaji.

Virus Corona dengan nama Severe acute respiratory syndrome coronavirus 2 (SARSCoV-2) merupakan keluarga besar virus yang menyerang manusia dan hewan. Virus Corona yang menjadi asal usul penyakit COVID-19 merupakan virus jenis baru yang ditemukan pada tahun 2019, sebelum ini belum pernah diidentifikasi menyerang manusia [2]. Pencetus nama penyakit COVID-19 adalah World Health Organization (WHO). Pada tubuh manusia, biasanya virus ini dapat mengakibatkan infeksi saluran pernapasan, seperti flu, ataupun penyakit akut seperti Middle East Respiratory Syndrome (MERS) dan Sindrom Pernapasan Akut Berat/ Severe Acute Respiratory Syndrome (SARS). Jika tidak ditangani dengan baik, maka dapat menyebabkan kematian. Virus ini dapat menyerang semua orang, dari bayi hingga lansia. Namun, ada beberapa kelompok manusia yang lebih beresiko terpapar virus Corona, diantaranya perokok dan pengisap vape, usia lanjut, dan penderita penyakit kronis Virus Corona yang pertama kali muncul di Wuhan, Provinsi Hubei, Tiongkok ini telah menyebar hampir ke seluruh dunia termasuk Indonesia.

Virus Corona dapat ditularkan melalui tetesan cairan yang berasal dari batuk dan bersin, kontak langsung seperti menyentuh dan berjabat tangan, dan menyentuh benda atau permukaan yang terinfeksi, kemudian menyentuh mulut, hidung, atau mata sebelum mencuci tangan. Karena penyebaran virus ini sangat mudah, maka virus ini menular dengan cepat sampai akhirnya menyebar di Indonesia. Gejala awal penyakit ini menyerupai gejala flu seperti demam, batuk, sakit tenggorokan dan lainnya. Setelah itu, gejala akan bertambah parah menjadi demam tinggi, batuk berdahak berdarah, bahkan sesak napas. Namun dengan imun yang baik, maka virus Corona tidak mudah menyerang tubuh penderita. Virus Corona juga dapat bertahan hidup di permukaan selama beberapa hari. 


\subsection{Rumusan Masalah}

Berdasarkan latar belakang yang telah dijelaskan di atas, penelitian ini memiliki rumusan masalah:

1. Bagaimana pandemi COVID-19 mempengaruhi keberjalanan tradisi Ngabuburit.

2. Apakah komunitas mahasiswa di Kota Bandung ingin melaksanakan tradisi Ngabuburit?

3. Apakah metode yang sebaiknya digunakan untuk melaksanakan tradisi Ngabuburit saat masa pandemi di Kota Bandung?

\subsection{Tujuan Penelitian}

1. Mengetahui pengaruh pandemi COVID-19 terhadap tingkat partisipasi mahasiswa dalam melaksanakan tradisi Ngabuburit.

2. Mengetahui minat komunitas mahasiswa di Kota Bandung terhadap pelaksanaan tradisi Ngabuburit.

3. Mengetahui metode yang sebaiknya digunakan untuk melaksanakan tradisi Ngabuburit saat pandemi di Kota Bandung.

\section{METODE PENELITIAN}

\subsection{Objek Penelitian}

Objek penelitian penulis merupakan mahasiswa yang berkuliah dan berada di Kota Bandung selama bulan puasa.

\subsection{Jenis Penelitian}

Penelitian ini berupa penelitian deskriptif, yang berarti penulis akan membandingkan adanya pandemi COVID-19 dengan minat, partisipasi, dan metode yang digunakan untuk melaksanakan Ngabuburit.

\subsection{Metode Pengumpulan Data}

Penelitian ini menggunakan metode penelitian gabungan. Metode penelitian gabungan adalah metode yang menggunakan metode kualitatif pada satu fase penelitian, dan metode penelitian kuantitatif pada fase lainnya [3]. Penelitian kualitatif berupa studi literatur untuk memberikan gambaran latar belakang penelitian. Metode penelitian kuantitatif menggunakan kuesioner daring, yang akan disebar ke berbagai komunitas mahasiswa di Kota Bandung.

\section{HASIL DAN PEMBAHASAN}

\subsection{Pengaruh Pandemi Covid-19 Terhadap Pelaksanaan Tradisi Ngabuburit}

Melalui penyebaran kuesioner daring, kami mendapatkan responden sebanyak 161 orang, namun kami hanya menggunakan 102 data, diantaranya merupakan mahasiswa berdomisili di Kota Bandung selama pandemi berlangsung. Berdasarkan hasil survei yang telah dibuat dan dijabarkan pada Gambar 1 dan Gambar 2, sebanyak $66.7 \%$ responden mengatakan bahwa mereka melaksanakan tradisi Ngabuburit sebelum pandemi. Angka tersebut turun menjadi $16.7 \%$ saat pandemi berlangsung. Kedua data tersebut menggambarkan pengurangan partisipasi mahasiswa dalam melaksanakan tradisi Ngabuburit. Berdasarkan Gambar 3, jika 
kedua data tersebut dibandingkan, dapat dilihat bahwa mayoritas responden yang sebelum pandemi memilih jawaban "Ya", berubah memilih "Tidak" saat pandemi.

Dari hasil kuesioner, beberapa faktor responden tidak melakukan tradisi Ngabuburit saat pandemi COVID-19 adalah karena ingin mematuhi protokol yang diberikan oleh pemerintah, takut tertular melalui kontak fisik dengan lingkungan maupun masyarakat yang sudah terinfeksi virus corona, malas menggunakan masker dan keamanan lainnya, tidak diperbolehkan orang tua, dan sibuk dengan pekerjaan lain. Sementara itu, untuk beberapa responden yang tetap melakukan ngabuburit saat pandemi mengatakan bahwa faktor penghambat terlaksananya tradisi Ngabuburit saat pandemi COVID-19 adalah social distancing, banyaknya masyarakat yang kurang tertib dalam memakai keamanan dan kebersihan diri sehingga menimbulkan paranoid (rasa takut yang berlebihan) dan rasa kurang nyaman saat bepergian keluar, kesulitan dalam segi ekonomi saat pandemi, berkurangnya restoran atau tempat-tempat hiburan yang biasanya dikunjungi saat ngabuburit, serta vibes Ngabuburit yang kurang terasa saat pandemi menimbulkan berkurangnya antusias responden untuk melakukan tradisi Ngabuburit.

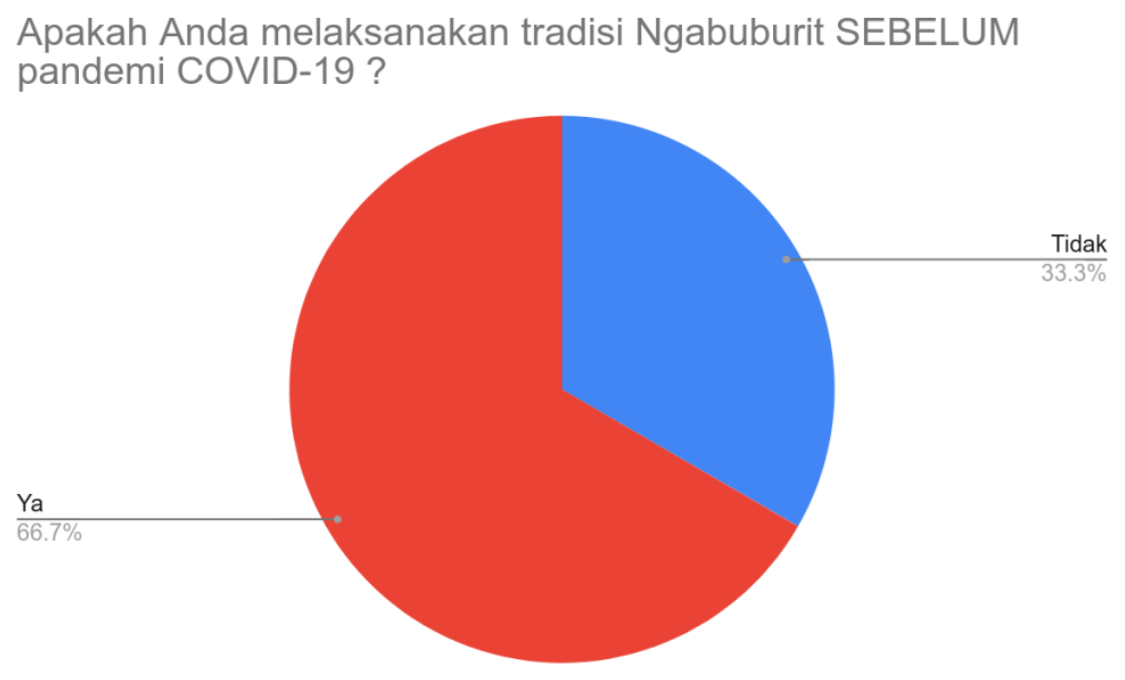

Gambar 1. Partisipasi Mahasiswa Bandung dalam Pelaksanaan Tradisi Ngabuburit Sebelum Pandemi
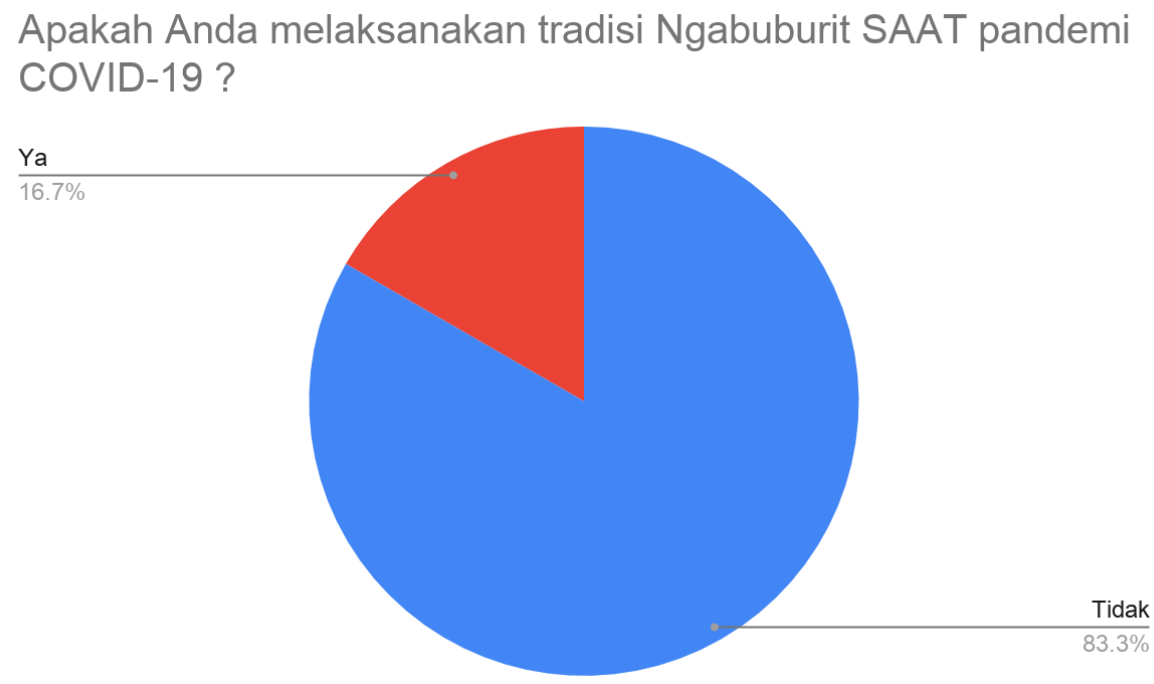

Gambar 2. Partisipasi Mahasiswa Bandung dalam Tradisi Ngabuburit Setelah Pandemi 


\section{Perbedaan Pilihan Partisipasi Ngabuburit \\ Sebelum dan Sesudah Pandemi \\ Ya Tidak}

80

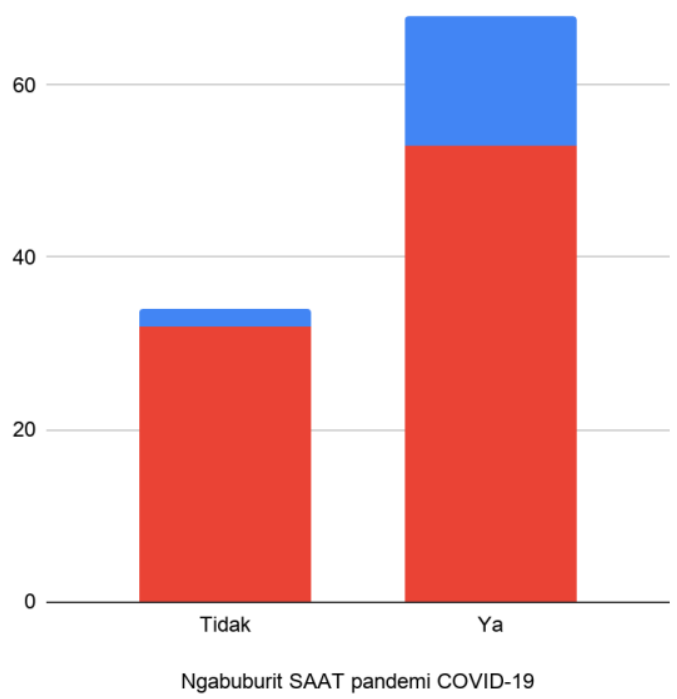

Gambar 3. Perbandingan Responden yang Mengubah Pilihan Sebelum dan Saat Pandemi

\subsection{Peminatan Mahasiswa Terhadap Tradisi Ngabuburit Saat Pandemi Covid-19}

Meskipun sebagian besar responden tidak melaksanakan Ngabuburit saat pandemi COVID-19, ternyata responden tersebut masih ingin melaksanakan tradisi Ngabuburit. Hal tersebut dapat dilihat pada Gambar 4 bahwa dari 85 responden yang tidak melaksanakan tradisi Ngabuburit saat pandemi, terdapat 53 responden yang sebenarnya ingin melaksanakan tradisi Ngabuburit dan sisanya tidak. Hal ini menunjukkan bahwa mayoritas mahasiswa yang berdomisili di Kota Bandung masih memiliki minat yang tinggi untuk melaksanakan tradisi Ngabuburit.

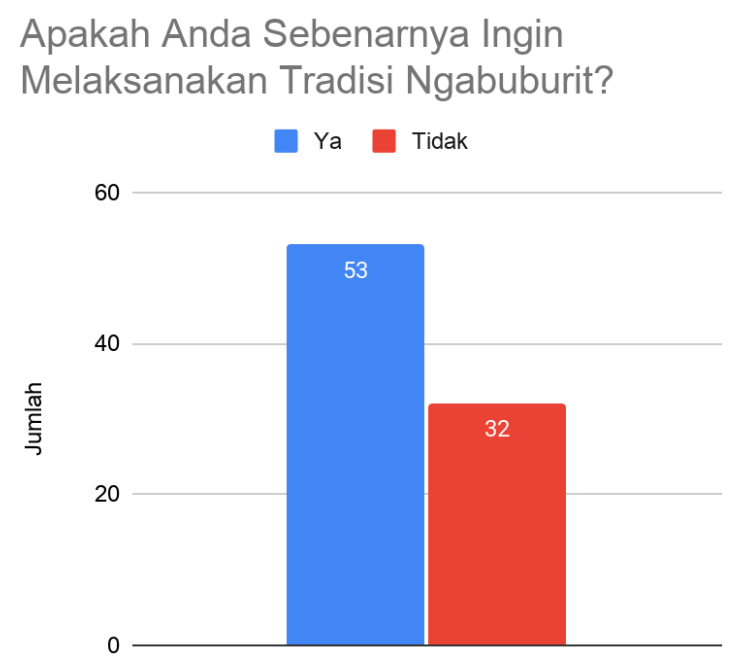

Gambar 4. Jumlah Responden yang Sebenarnya Ingin Melaksanakan Tradisi Ngabuburit 


\subsection{Tingkat Kebahagiaan Sebelum Dan Saat Pandemi Covid-19}

Manusia merupakan makhluk sosial yang membutuhkan banyak interaksi sosial. Menurut Seligman [4], kehidupan sosial merupakan salah satu faktor yang mempengaruhi kebahagiaan. Khususnya untuk mahasiswa, interaksi sosial merupakan salah satu hal penting yang sangat mempengaruhi kehidupannya. Salah satu ciri interaksi sosial adalah dimulai dengan adanya kontak sosial secara langsung [5]. Dengan adanya pandemi COVID-19, jumlah interaksi sosial yang dapat dilakukan secara tatap muka dibatasi untuk memutus rantai penyebaran virus Corona. Ngabuburit, sebagai tradisi yang mendukung interaksi sosial antar manusia, merupakan wadah yang sangat baik untuk memenuhi kebutuhan sosial mahasiswa khususnya dalam meningkatkan kebahagiaan.

Berdasarkan hasil survei yang telah dibuat dan dijabarkan pada Gambar 3, diketahui saat pandemi COVID-19, tingkat partisipasi tradisi Ngabuburit menurun dibandingkan dengan partisipasi sebelum terdampak pandemi COVID-19. Pembahasan mengenai peminatan responden terhadap tradisi Ngabuburit yang telah dijabarkan sebelumnya, mendukung Gambar 5 yang membahas tentang seberapa besar perubahan tingkat kebahagiaan sebelum dan saat pandemi terjadi. Mayoritas responden mengalami penurunan kebahagiaan yang terlihat dari rata-rata kebahagiaan (skala 1-10) sebelum pandemi sebesar 8.196, berubah menjadi 5.617 setelah memasuki masa pandemi. Dengan kata lain, berkurangnya wadah interaksi sosial yang biasanya diberikan oleh kegiatan berjalan-jalan seperti Ngabuburit telah membuat tingkat kebahagiaan mayoritas responden menurun.

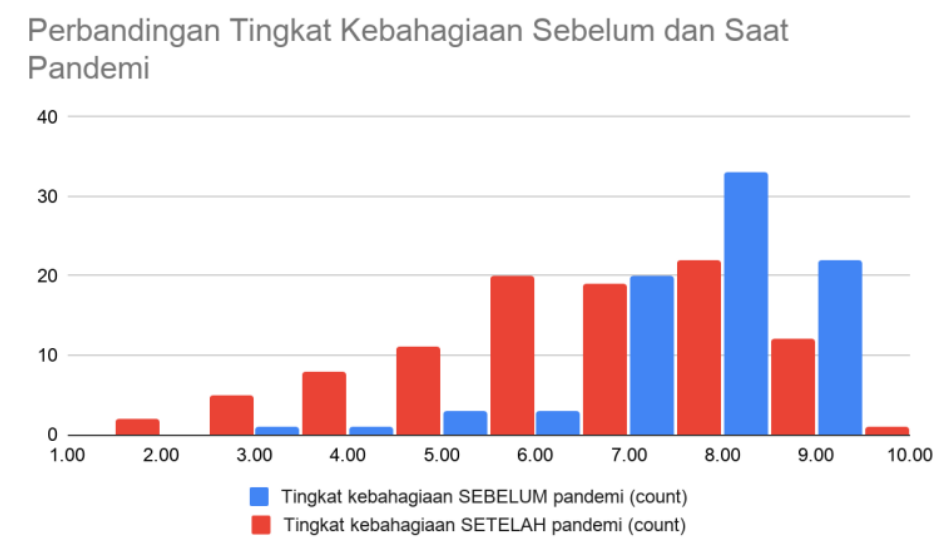

Gambar 5. Perbandingan Tingkat Kebahagiaan Sebelum dan Saat Pandemi
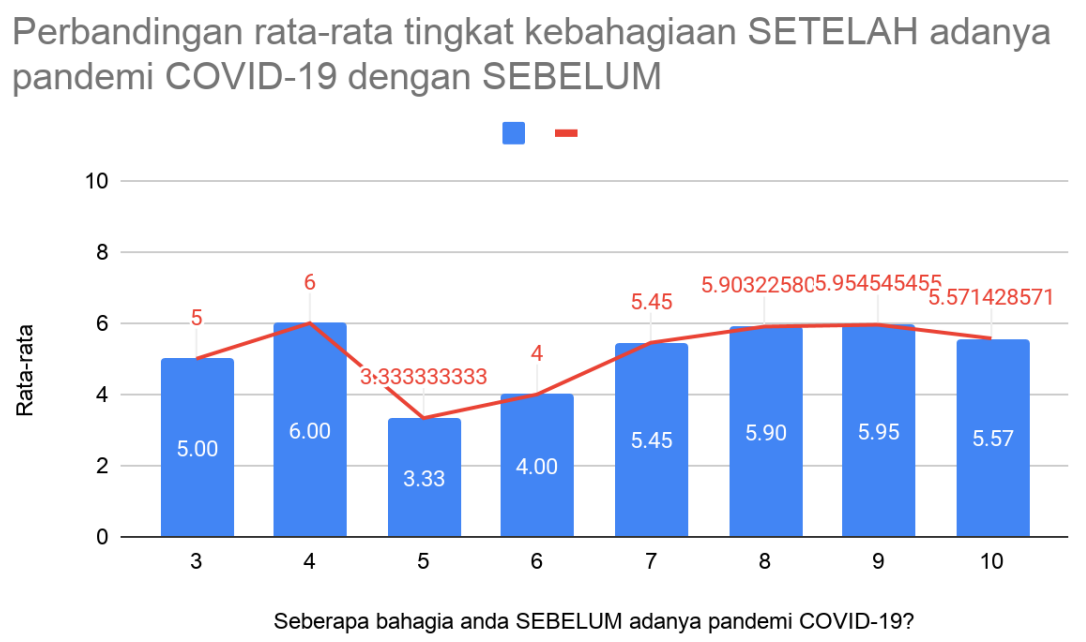

Gambar 6. Perbandingan Rata-rata Tingkat Kebahagiaan Setelah Adanya Pandemi COVID-19 dengan Sebelum 


\subsection{Metode Pelaksanaan Ngabuburit Yang Paling Diminati Mahasiswa Di Kota Bandung}

Dengan peminatan terhadap tradisi Ngabuburit yang lumayan tinggi meski pandemi, cara alternatif untuk melaksanakan tradisi Ngabuburit tersebut sangat dibutuhkan. Di dalam kuesioner yang disebarkan, terdapat pertanyaan mengenai metode pelaksanaan Ngabuburit yang paling diminati oleh mahasiswa di Kota Bandung. Melalui kuesioner tersebut, didapatkan bahwa 39.6\% responden ingin melaksanakan kegiatan secara daring, 36.6\% responden ingin melaksanakan kegiatan secara campuran luring dan daring, $22.8 \%$ responden ingin melaksanakan kegiatan secara luring dengan protokol kesehatan seperti yang dianjurkan oleh pemerintah, dan $1.0 \%$ menyatakan metode bergantung pada jumlah orang yang hadir dalam suatu Ngabuburit (fleksibel).

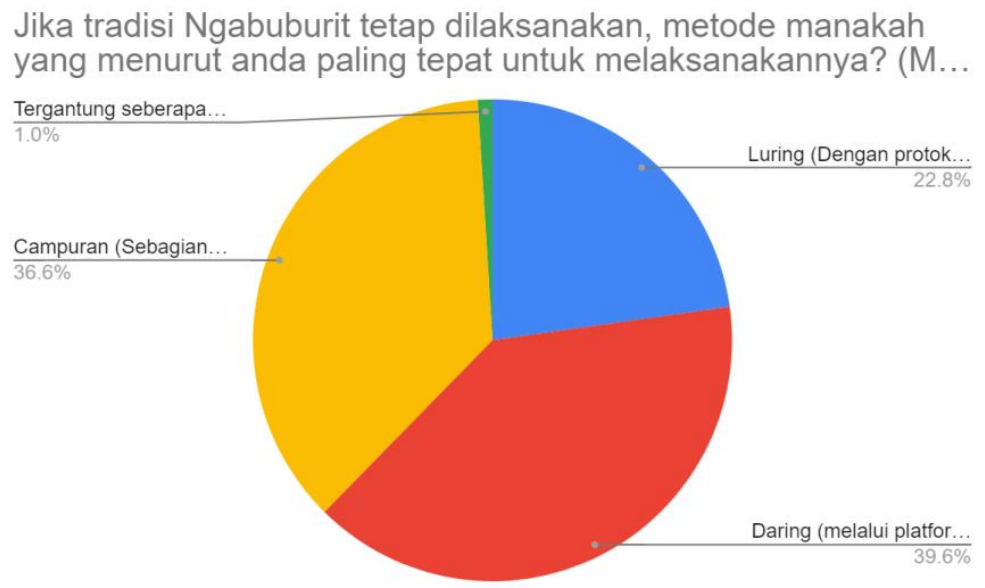

Gambar 7. Metode Pelaksanaan Tradisi Ngabuburit yang Paling Diminati

Ketiga metode tersebut memiliki keuntungan dan kekurangannya masing-masing. Dengan metode daring, peserta Ngabuburit dapat mendapatkan interaksi sosial yang dibutuhkannya walaupun pelaksanaannya sangat terbatas oleh perangkat yang dimiliki peserta tersebut. Faktor-faktor seperti kekuatan koneksi internet dan kualitas kamera dan mikrofon menjadi hal yang harus diperhatikan. Keintiman interaksi yang terjadi juga terbatas karena kegiatan yang dapat dilakukan hanya dapat dilakukan secara virtual. Dengan metode campuran, beberapa faktor yang ada pada metode daring akan teratasi, namun hanya untuk sebagian orang dan dapat meningkatkan risiko tertular. Dengan metode luring, risiko tertular penyakit COVID19 lebih tinggi karena interaksi yang terjadi antar manusia lebih banyak dan jarak antaranya lebih dekat.

Dari hasil survei yang dilakukan, mayoritas memilih metode daring untuk melaksanakan tradisi Ngabuburit. Akan dilampirkan beberapa kegiatan yang dapat dilakukan saat Ngabuburit dengan metode Daring. Pertama, dapat dilakukan buka puasa bersama melalui berbagai aplikasi dan platform daring yang saat ini sudah banyak tersedia. Selain melestarikan tradisi Ngabuburit, buka puasa bersama secara daring juga dapat meningkatkan kebersamaan dan mempererat hubungan pertemanan. Kedua, kegiatan yang dapat dilakukan adalah nonton bersama melalui platform yang tersedia seperti Zoom, Google Meet, ataupun platform lainnya. Aplikasi yang dapat digunakan, seperti Netflix Party, Amazon Watch Party, MetaStream, dan Scener. Aplikasi tersebut juga menyediakan ruang obrolan atau live chat. Selain itu, mahasiswa dapat memakai fitur share screen dari platform yang tersedia untuk menampilkan film yang akan ditonton bersama. Kegiatan ini dapat mengurangi rasa bosan atau jenuh saat dilakukannya tradisi Ngabuburit secara daring. Ketiga, dapat dilakukan berburu takjil online yang dapat dipesan melalui aplikasi online. Selain lebih aman dan mengikuti peraturan pemerintah, esensi tradisi Ngabuburit juga tidak hilang. Keempat, dapat melakukan jalan-jalan virtual dengan bantuan aplikasi dan platform online. Kegiatan ini dapat dilakukan dengan mengikuti acara 
jalan-jalan virtual yang diadakan pihak tertentu, contohnya kegiatan liburan virtual yang diadakan Ancol saat bulan puasa. Selain itu, dapat pula dilaksanakan secara mandiri melalui aplikasi, contohnya Google Maps.

\section{KESIMPULAN}

Tradisi Ngabuburit merupakan salah satu tradisi yang biasanya dilakukan selama bulan puasa sembari menunggu azan magrib, terutama di wilayah Jawa Barat. Tradisi ini biasa dilakukan dengan cara berkumpul dengan teman, jalan-jalan, dan membeli jajanan kuliner. Namun tradisi ini terhambat karena adanya Pandemi COVID-19. Pandemi disebabkan oleh virus Corona dengan nama Severe acute respiratory syndrome coronavirus 2 (SARS-CoV-2) yang menyebar dengan cepat serta mematikan.

Terdapat beberapa hal yang ditinjau, yaitu pengaruh pandemi COVID-19 terhadap tradisi Ngabuburit, pengaruh minat mahasiswa Bandung terhadap tradisi Ngabuburit, dan metode Ngabuburit yang paling baik dilakukan saat pandemi COVID-19. Untuk pengaruh pandemi COVID-19 terhadap tradisi ngabuburit, ternyata pandemi COVID-19 menyebabkan terhambatnya tradisi Ngabuburit di Bandung.

Dengan terhambatnya tradisi Ngabuburit, ternyata berdampak juga terhadap tingkat kebahagiaan mahasiswa Bandung yang menurun seiring dengan hadirnya COVID-19. Untuk minat mahasiswa Bandung terhadap tradisi Ngabuburit, dibuktikan bahwa ternyata banyak mahasiswa Bandung ingin melaksanakan ngabuburit, artinya sejauh ini tradisi Ngabuburit masih dijalankan dan masih dilestarikan di Bandung.

\section{SARAN}

Dengan banyaknya minat melaksanakan tradisi Ngabuburit, terdapat beberapa metode yang dapat dilakukan untuk tetap dapat melaksanakan tradisi Ngabuburit saat pandemi. Salah satu metode yang paling banyak dipilih adalah metode Daring, yaitu melaksanakan tradisi Ngabuburit secara online, tidak bertatap muka secara langsung.

Ada beberapa hal yang dapat dilakukan dengan metode daring, diantaranya berbuka puasa bersama, nonton bersama, berburu takjil bersama, jalan-jalan virtual dengan bantuan aplikasi dan platform online. Selain dapat melakukan tradisi Ngabuburit saat pandemi, hal ini juga dapat mengurangi resiko seseorang terkena penyakit COVID-19 serta dapat memutus rantai penyebaran COVID-19. Berbagai kemajuan teknologi yang telah ada nyatanya sangat membantu keberlangsungan tradisi Ngabuburit secara daring. Sehingga walaupun tradisi Ngabuburit tidak dapat dilakukan seperti biasanya, namun tradisi ini tetap dapat dilestarikan dengan bantuan platform dan aplikasi yang ada.

\section{DAFTAR PUSTAKA}

[1] M. Sumantri, Kamus Sunda-Indonesia. Jakarta: Pusat Pembinaan dan Pengembangan Bahasa, Departemen Pendidikan dan Kebudayaan, 1985.

[2] C. Sohrabi et al., "World Health Organization declares global emergency: A review of the 2019 novel coronavirus (COVID-19)," Int. J. Surg., vol. 76, pp. 71-76, Apr. 2020.

[3] Y. A. Muri, Metode Penelitian Kuantitatif, Kualitatif \& Penelitian Gabungan. Prenada Media, 2016. 
[4] M. E. P. Seligman, Authentic Happiness. Random House Australia, 2011.

[5] N. Malentika, Itryah, and M. Mawardah, "Hubungan Antara Interaksi Sosial Dengan Suasana Hati Pada Mahasiswa," Jurnal Ilmiah Psyche, vol. 11, no. 2, pp. 97-106, 2017.

[6] N. Mona, "Konsep Isolasi Dalam Jaringan Sosial Untuk Meminimalisasi Efek Contagious (Kasus Penyebaran Virus Corona Di Indonesia)," Jurnal Sosial Humaniora Terapan, vol. 2, no. 2, pp. 117-125, Jan. 2020.

[7] L. K. Palindangan, "Tanggapan Kritis Terhadap Jumlah Covid -19 di Indonesia," TarFomedia, vol. 1, no. 2, pp. 47-53, 2020.

[8] M. F. Nugraha, Sulasman, and U. Supendi, "Tradisi Keagamaan Masyarakat Kota Bandung di Bulan Ramadan Tahun 1990-2000," Historia Madania, vol. 2, no. 2, pp. 75-90, 2018.

[9] P. Pamungkas, "Ngabuburit," Tribun News Wiki, Apr. 23, 2020. www.tribunnewswiki.com/2020/04/23/ngabuburit (accessed Oct. 22, 2020).

[10] I. Putri, "PSBB, Ini Dia Cara Buka Bersama Seru dan Aman Selama Ramadhan," detikfood, Apr. 25, 2020. https://food.detik.com/berita-boga/d4991008/psbb-ini-dia-cara-buka-bersama-seru-dan-aman-selama-ramadhan (accessed Oct. 22, 2020).

[11] A. Ardiansyah, "Hubungan Antara Dukungan Sosial Teman Sebaya dengan Kebahagiaan pada Mahasiswa," S.Psi, Universitas Islam Negeri Sultan Sarif Kasim Riau, 2014.

[12] M. Yohannes, “Apa Itu Ngabuburit dan Bagaimana Asal-Usulnya?," Traveloka, Apr. 28, 2020. https://www.traveloka.com/en-id/explore/tips/apa-itu-pengertianngabuburit-acc/29880 (accessed Oct. 26, 2020).

[13] M. M. Drehem, “Asal Mula Ngabuburit,” Geotimes, Jun. 03, 2019. https://geotimes.co.id/opini/asal-mula-ngabuburit/ (accessed Oct. 22, 2020).

[14] R. I. Fatimah, "Dampak Meningkatnya Harga Masker di Tengah Mewabahnya Covid-19 di Kalangan Masyarakat Ditinjau dari Sudut Pandang Tindakan Manusia," https://osf.io/j5pn9, Universitas Katolik Widya Mandala Surabaya, 2020.

[15] Yuliana, "Corona virus diseases (Covid-19): Sebuah tinjauan literatur," Wellness and Healthy Magazine, vol. 2, no. 1, pp. 187-192, Feb. 2020.

[16] E. Maemunah, "Medan Makna Aktivitas Tangan 'Menyakiti' dalam Verba Bahasa Sunda," Kandai, vol. 15, no. 2, pp. 249-260, Nov. 2019.

[17] H. T. Siagian, "Mencari Kelompok Berisiko Tinggi Terinfeksi Virus Corona 
dengan Discourse Network Analysis," Jurnal Kebijakan Kesehatan Indonesia, vol. 9, no. 2, pp. 98-106, Jun. 2020.

[18] Kumparan, "Cara Mudah Nobar Film secara Online, Pakai Netflix hingga YouTube," Kumparan, Jul. 11, 2020. https://kumparan.com/kumparantech/caramudah-nobar-film-secara-online-pakai-netflix-hingga-youtube-1tkhPALFWUc (accessed Oct. 26, 2020).

[19] C.-C. Lai, T.-P. Shih, W.-C. Ko, H.-J. Tang, and P.-R. Hsueh, "Severe acute respiratory syndrome coronavirus 2 (SARS-CoV-2) and coronavirus disease2019 (COVID-19): The epidemic and the challenges," Int. J. Antimicrob. Agents, vol. 55, no. 3, Feb. 2020, doi: 10.1016/j.ijantimicag.2020.105924.

[20] B. Etikasari, T. D. Puspitasari, A. A. Kurniasari, and L. Perdanasari, "Sistem Informasi Deteksi Dini COVID-19," Jurnal Teknik Elektro dan Komputer, vol. 9, no. 2, pp. 101-108, 2020. 